\title{
Genetic Association of Apolipoprotein E with Age-Related Macular Degeneration
}

\author{
Caroline C. W. Klaver, ${ }^{1,2}$ Mike Kliffen, ${ }^{3}$ Cornelia M. van Duijn, ${ }^{1}$ Albert Hofman, ${ }^{1}$ Marc Cruts, ${ }^{4}$ \\ Diederick E. Grobbee, ${ }^{1}$ Christine van Broeckhoven, ${ }^{4}$ and Paulus T. V. M. de Jong ${ }^{1,5,6}$ \\ Departments of ${ }^{1}$ Epidemiology and Biostatistics, ${ }^{2}$ Ophthalmology, and ${ }^{3}$ Pathology, Erasmus University Medical School, Rotterdam; ${ }^{4}$ Laboratory \\ of Neurogenetics, Flanders Interuniversity Institute of Biotechnology, Born-Bunge Foundation, and Department of Biochemistry, University of \\ Antwerp, Antwerp; and ${ }^{5}$ The Netherlands Ophthalmic Research Institute, and ${ }^{6}$ Academic Medical Centre, Amsterdam
}

\section{Summary}

Age-related macular degeneration (AMD) is the most common geriatric eye disorder leading to blindness and is characterized by degeneration of the neuroepithelium in the macular area of the eye. Apolipoprotein E (apoE), the major apolipoprotein of the CNS and an important regulator of cholesterol and lipid transport, appears to be associated with neurodegeneration. The apoE gene (APOE) polymorphism is a strong risk factor for various neurodegenerative diseases, and the apoE protein has been demonstrated in disease-associated lesions of these disorders. Hypothesizing that variants of APOE act as a potential risk factor for $\mathrm{AMD}$, we performed a geneticassociation study among 88 AMD cases and 901 controls derived from the population-based Rotterdam Study in the Netherlands. The APOE polymorphism showed a significant association with the risk for AMD; the APOE $\epsilon 4$ allele was associated with a decreased risk (odds ratio 0.43 [95\% confidence interval $0.21-0.88$ ]), and the $\epsilon 2$ allele was associated with a slightly increased risk of AMD (odds ratio 1.5 [95\% confidence interval 0.8-2.82]). To investigate whether apoE is directly involved in the pathogenesis of AMD, we studied apoE immunoreactivity in 15 AMD and 10 control maculae and found that apoE staining was consistently present in the disease-associated deposits in AMD-maculae-that is, drusen and basal laminar deposit. Our results suggest that APOE is a susceptibility gene for AMD.

Received August 18, 1997; accepted for publication April 22, 1998 ; electronically published May 29, 1998.

Address for correspondence and reprints: Dr. Paulus de Jong, Box 12141, 1100 AC Amsterdam, The Netherlands. E-mail: dejong @epib.fgg.eur.nl or P.dejong@ioi.knaw.nl

(C) 1998 by The American Society of Human Genetics. All rights reserved. 0002-9297/98/6301-0030\$02.00

\section{Introduction}

Age-related macular degeneration (AMD) is the most common cause of blindness in the elderly in developed countries (Sommer et al. 1991; Klein et al. 1995; Attebo et al. 1996; Klaver et al. 1998), severely affecting $>10 \%$ of octo- and nonagenarians (Vingerling et al. 1995). Histopathologically, the hallmark of early AMD is accumulation of extracellular drusen and basal laminar deposit (van der Schaft et al. 1992; Green and Enger 1993; Kliffen et al. 1997); the end stage is characterized by a complete degeneration of the neurosensory retina and of the underlying retinal pigment epithelium in the macular area (Sarks 1976). The etiology of AMD is largely unknown, but the current understanding is that AMD is a genetically complex eye disorder (Heiba et al. 1994; Klaver et al. 1997; Seddon et al. 1997) possibly caused by a variety of molecular defects. Less frequent macular disorders have been linked to a significant number of genomic loci (Small et al. 1992, 1996; Stone et al. 1992, 1994; Evans et al. 1994; Gregory et al. 1996), whereas mutations in the TIMP3 (Weber et al. 1994) and peripherin/RDS (Nichols et al. 1993; Weleber et al. 1993; Wells et al. 1993; Keen et al. 1994; Nakazawa et al. 1994; Hoyng et al. 1996) genes have been identified in specific earlier-onset retinal dystrophies. Despite close clinical similarities between AMD and these disorders, neither the TIMP3 gene nor the peripherin/RDS gene has been associated with AMD. A recent publication reports that the Stargardt disease gene shows a consistent variation of the ABCR gene in $4.2 \%$ of $A M D$ patients, significantly different from the $0.45 \%$ in population controls (Allikmets et al. 1997). This variation may account for $\sim 4 \%$ of the total occurrence of AMD, and, presumably, more genes are involved.

Apolipoprotein E (apoE) is unique among apolipoproteins, in its special relevance to nervous tissue. It mobilizes and redistributes lipids, in maintenance and repair of neuronal cell membranes (Pitas et al. 1987; Mahley 1988; Boyles et al. 1989), thereby playing a pivotal role in the reinnervation process following peripheral nerv- 
Table 1

Distribution of APOE Genotypes and Allele Frequency

\begin{tabular}{lcc}
\hline & \multicolumn{2}{c}{ FREQUENCY IN } \\
\cline { 2 - 3 } APOE CHARACTERISTIC & $\begin{array}{c}\text { AMD Cases } \\
(n=88)\end{array}$ & $\begin{array}{c}\text { Controls } \\
(n=901)\end{array}$ \\
\hline Genotype: & & \\
E2E2 & .000 & .010 \\
E2E3 & .227 & .144 \\
E2E4 & .023 & .017 \\
E3E3 & .636 & .555 \\
E3E4 & $.114^{\mathrm{a}}$ & .252 \\
E4E4 & .000 & .022 \\
Allele frequency: & & .090 \\
$\epsilon 2$ & .125 & .753 \\
$\epsilon 3$ & .806 & .156 \\
$\epsilon 4$ & $.068^{\mathrm{b}}$ & \\
\hline
\end{tabular}

${ }^{a} P=.02$, compared with controls.

b $P=.004$, compared with controls. Hardy-Weinberg equilibrium: cases $\chi^{2}=2.27, P=.26$; controls $\chi^{2}=4.24, P=.11$.

ous system (Ignatius et al. 1986) and CNS injury (Poirier et al. 1993). The gene for apoE (APOE), located on chromosome 19q13.2 (Olaisen et al. 1982), is polymorphic, with the occurrence of three common alleles: $\epsilon 2, \epsilon 3$, and $\epsilon 4$. The $\epsilon 3$ allele is considered to be the ancestral allele; and $\epsilon 2$ and $\epsilon 4$ are considered as variants, on the basis of single point mutations (Mahley 1988). APOE's polymorphism is of particular interest within the framework of neurodegeneration, for it is strongly associated with the risk of Alzheimer disease (Strittmatter et al. 1993; Farrer et al. 1997) and may be associated with various other neurodegenerative disorders (Amouyel et al. 1994; Al-Chalabi et al. 1996). Moreover, apoE is expressed in lesions that characterize Alzheimer disease, Down syndrome, and prion diseases (Namba et al. 1991; Wisniewski and Frangione 1992).

Expanding these data to a neurodegenerative eye disorder, we investigated the possible role of APOE in AMD in a genetic-association study. We have used a case-control design implemented within a population-based study, to assess whether the APOE alleles are associated with the risk of AMD. In a subsequent immunohistochemical procedure, we studied apoE expression in human maculae with and without AMD.

\section{Subjects and Methods}

We studied APOE genotype and allele frequencies in AMD cases and in controls in the Rotterdam Study, a population-based study, in the Netherlands, of subjects age $\geqslant 55$ years. The rationale and design of the Rotterdam Study have been described elsewhere (Hofman et al. 1991; Vingerling et al. 1995). A total of 6,775 participants in that study had undergone an extensive ophthalmological examination, including fundus photog- raphy. Diagnosis of AMD was based on grading of fundus transparencies according to an internationally accepted classification system (Bird et al. 1995). Cases were all subjects with end stages of AMD on whom data on APOE genotype were available $(n=88)$. The end stages comprised atrophic macular degeneration-that is, geographic areas of atrophy of the retinal pigment epithelium and choriocapillaris-and neovascular macular degeneration-that is, serous or hemorrhagic detachment of the pigment epithelium or choroidal neovascularization. Controls were a randomly selected sample of study subjects without atrophic or neovascular AMD $(n=901)$. There were no significant differences, in baseline characteristics, between cases and controls, apart from the known risk factors age and atherosclerosis (mean age [SD] 81 [8] vs. 69 [9] years, $P<.001$; frequency of lower-extremity arterial disease [an indicator of atherosclerosis] $37 \%$ vs. $16 \%, P<.001$ [ageadjusted prevalence data]).

Genomic DNA was extracted from peripheral blood leukocytes, and the subsequent analysis of APOE genotypes was performed as described elsewhere (Wenham et al. 1991; van Duijn et al. 1994). Genotype and allele distributions between cases and controls were calculated by use of $\chi^{2}$ statistics. With multiple logistic-regression analysis, we estimated the odds ratio (OR), as a measure of relative risk, for the various genotypes, using the ancestral E3E3 genotype as a reference. ORs were adjusted for age and gender and, in a separate analysis, for the presence of lower-extremity arterial disease, to investigate the possible confounding effect of atherosclerosis.

For the immunohistochemical study, maculae were obtained from 25 human eye-bank eyes from 25 subjects. The times from death to processing of the maculae were 1-10 h, with a mean of $7 \mathrm{~h}$. Tissues were fixed in $4 \%$ formaldehyde, embedded in paraffin, and sectioned into $5-\mu \mathrm{m}$ thicknesses. Sections were stained with hematoxylin-eosin, the periodic-acid-Schiff reaction, and Mallory staining and subsequently were classified histologically according to quantification of drusen and basal laminar deposit, as described elsewhere (van der Schaft et al. 1992; Kliffen et al. 1997). Accordingly, maculae with no or only solitary patches of basal laminar deposit and with no more than three drusen were classified as controls $(n=10)$; and maculae with a continuous layer of basal laminar deposit and/or with many or confluent drusen were classified as cases $(n=15)$. Cases were, although not significantly, older than controls (mean age [SD] 82 [10] vs. $72[14]$ years; $P=.08$ ). After deparaffinization and rehydration, sections were incubated with $5.5 \mathrm{mU} / \mathrm{ml}$ pronase $\mathrm{E}$ (Sigma), to reveal antigenic epitopes of APOE, and were placed in a Sequenza Immunostaining Workstation (Life Sciences International). Sections were successively incubated with a mouse-monoclonal antibody directed against apoE 


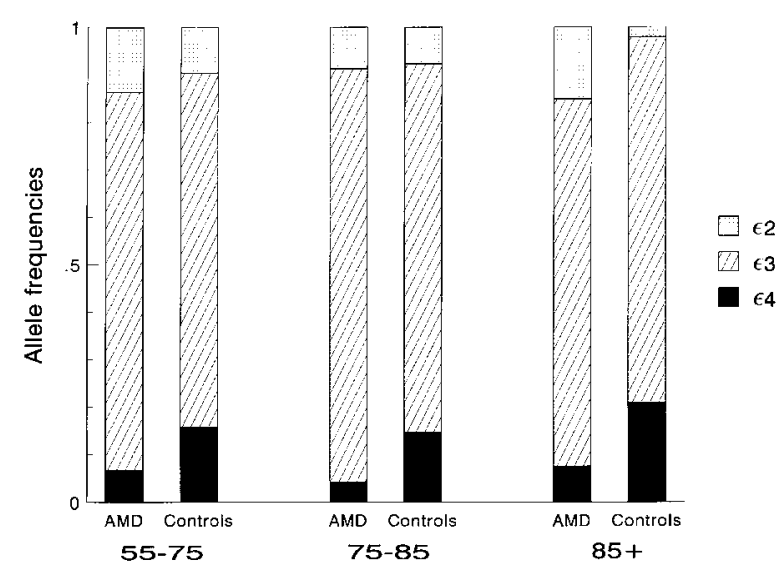

Figure 1 APOE allele frequencies in the age categories of 55-75 years, $75-85$ years, and $>85$ years: the number of cases and the number of controls, respectively, in these successive categories are 17 and 687, 40 and 188 , and 26 and 31.

(clone 3D12, dilution 1:25; Monosan), biotinylated-secondary antibodies (Multilink, dilution 1:75; Biogenex), and alkaline-phosphatase-conjugated streptavidin (dilution 1:50; Biogenex). Between these incubations, sections were washed thoroughly with PBS. After a final rinsing with $0.2 \mathrm{M}$ Tris- $\mathrm{HCl} \mathrm{pH} 8.0$, the presence of apoE was visualized with $0.3 \%$ New Fuchsin/Tris- $\mathrm{HCl}$ (Sigma).

\section{Results}

APOE genotype and allele distributions differed significantly between cases and controls (table 1). Compared with controls, the frequency of the APOE $\epsilon 4$ allele was significantly lower among cases (.07 in cases vs. 0.16 in controls; $P=.002$ ), whereas the frequency of the $\epsilon 2$ allele was, although not significantly, higher (.13 vs. .09; $P=.17$ ). Because the $\epsilon 4$ allele may adversely affect longevity, given its association with Alzheimer disease and coronary heart disease (Kervinen et al. 1993), we investigated the prevalence of the APOE alleles, as a function of age (fig. 1). There were no significant differences in allele frequencies in the three age groups, indicating that our findings cannot be explained by the age-distribution difference between cases and controls.

Table 2 shows the relative risks of AMD, for the different APOE alleles. When adjustment was made for age and sex, subjects with the $\epsilon 4$ allele were more than two times less likely to develop AMD than were subjects with the E3E3 genotype. Subjects with the $\epsilon 2$ allele were at a slightly, but not significantly, increased risk of AMD. Additional adjustment, for lower-extremity arterial disease, did not significantly alter the risk estimates (data not shown), suggesting that APOE and atherosclerosis are independent risk factors for AMD.

apoE immunoreactivity was present in the extracellular deposits that characterized the AMD maculae-that is, basal laminar deposit and soft drusen. Basal laminar deposit stained positive for apoE in 13 of 15 maculae with this type of deposit (fig. 2A), and drusen stained positive in 9 of 11 maculae with drusen (fig. 2B). One eye with atrophic AMD showed both a thick layer of basal laminar deposit and drusen staining positive for apoE (fig. 2C). In both case and control maculae, staining was seen in the outer collagenous zone of Bruch's membrane, in blood vessels, and in Müller cells. Particularly of interest is the finding that solitary, hard hyaline drusen, a type of deposit that is clinically not associated with AMD, did not show any apoE immunoreactivity.

\section{Discussion}

Our results show that the APOE polymorphism is significantly associated with the risk of AMD and that apoE is expressed in lesions that characterize AMD. A decreased risk of AMD was associated with the $\epsilon 4$ allele, whereas an increased risk was associated with the $\epsilon 2$ allele. The consistent immunoreactivity in soft drusen and basal laminar deposit in the AMD maculae suggests the importance of apoE in the pathogenesis of AMD.

Table 2

Relative Risk of AMD for the APOE Genotypes

\begin{tabular}{|c|c|c|c|c|}
\hline \multirow[b]{2}{*}{ APOE GENOTYPE } & \multicolumn{2}{|c|}{ No. OF } & \multicolumn{2}{|c|}{$\begin{array}{l}\text { OR (95\% CONFIDENCE } \\
\text { INTERVAL) }\end{array}$} \\
\hline & $\begin{array}{l}\text { AMD Cases } \\
(n=88)\end{array}$ & $\begin{array}{l}\text { Controls } \\
(n=901)\end{array}$ & Crude & Adjusted $^{\mathrm{b}}$ \\
\hline$E * 2$ & 22 & 154 & $1.28(.75-2.21)$ & $1.50(.80-2.82)$ \\
\hline E3E3 & 56 & 500 & Reference & Reference \\
\hline$E * 4$ & 12 & 262 & $.41(.22-.78)$ & $.43(.21-.88)$ \\
\hline
\end{tabular}

a APOE genotypes with the $\epsilon 2$ allele are grouped, and genotypes with the $\epsilon 4$ allele are grouped; subjects with the E2E4 genotype (2 of 88 cases, 15 of 901 controls) are present in both the $\mathrm{E}^{*} 2$ group and the $\mathrm{E}^{*} 4$ group.

b For age and gender. 


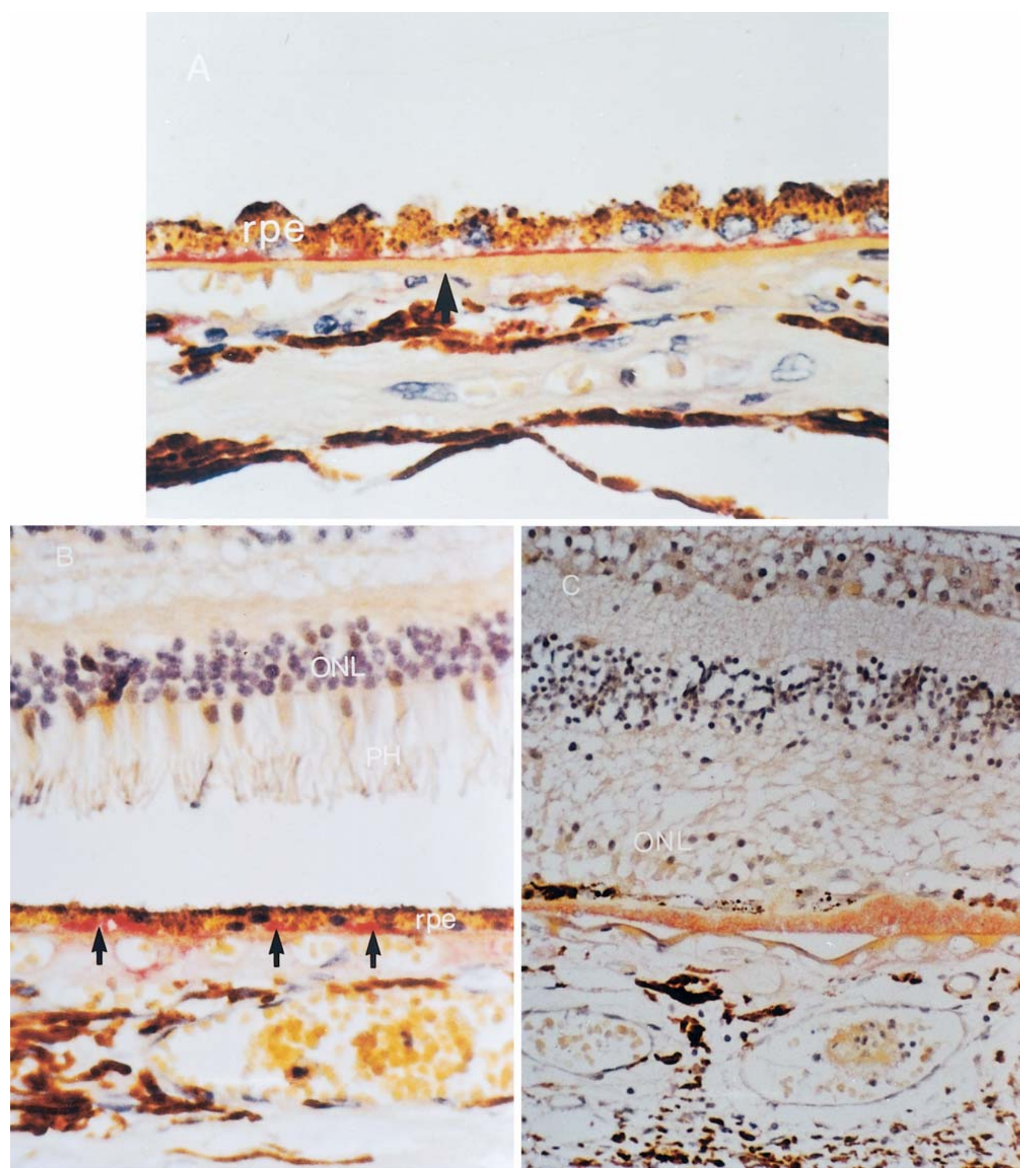

Figure 2 Immunohistochemistry of apoE in human maculae with AMD. Shown is positive staining $(r e d)$, of $(A)$ a thin layer of basal laminar deposit located between the retinal pigment epithelium (rpe) and Bruch's membrane (arrow), (B) soft drusen (arrows), and (C) thick layer of diffuse drusen in a subject with atrophic AMD (note disappearance of the photoreceptors and of most of the rpe). ONL $=$ outer nuclear layer; and $\mathrm{PH}=$ photoreceptors. (New Fuchsin; $\times 400$ ) 
We carefully avoided selection bias, a frequently encountered problem in association studies. Since cases and controls were both derived from the same homogeneous source population, and since the distribution of the APOE genotypes in cases and controls was in HardyWeinberg equilibrium, selection on the basis of genotype is unlikely. Moreover, the allele frequencies among the controls were in close agreement with the average allele frequencies estimated for the Dutch (Smit et al. 1988) and other Caucasian populations (Davignon et al. 1988). Because our extensive ophthalmologic examination demanded attentiveness from the study subjects, it may have selected against other neurodegenerative diseases-such as Alzheimer disease-which are known to be associated with increased $\epsilon 4$ frequency. Nevertheless, this cannot account for allele-frequency differences between cases and controls, because both groups underwent identical procedures. Finally, we showed that allele frequencies were similar across all age groups (fig. 1), indicating that the association cannot be explained on the basis of age.

Given the limited amount of data available, we can only speculate on the possible role of apoE in the neuronal dynamics of the macular area. In the CNS in general, a major physiological role for apoE is to mediate the interaction between apoE-containing lipoproteins and lipoprotein receptors, including the LDL receptor (Goldstein et al. 1983) and the LDL receptor-related protein receptor (LRP) (Kowal et al. 1989). After neuronal cell loss, large amounts of lipids are released from degenerating cell membranes and myelin, and, in response, astrocytes synthesize apoE, to bind the free cholesterol and lipids and to distribute them for reuse in cell-membrane biosynthesis (Poirier et al. 1993, 1995). ApoE may have a significant role in retinal membrane renewal. The high turnover of photoreceptor membranes (Grindle and Marshall 1978), especially in the macular area, makes cell-membrane remodeling of critical importance for maintaining the normal physiology of the retina. Failure of this process may then result in macular degeneration.

In the CNS, apoE is primarily synthesized by the major glial cell, the astrocyte. In our series, cell bodies of the Müller cell, the retinal analogue of the astrocyte, showed significant apoE expression, which may indicate a site of apoE production. This assumption is supported by findings from previous reports, which show that these cells are capable of apoE synthesis (Amaratunga et al. 1996) and which show increased expression in eyes with retinal damage (Kuhrt et al. 1997). The distribution of the LDL or LRP receptor in the neuroepithelium of the eye is unknown, and it is therefore unclear which cells are able to take up and process apoE-complexed molecules in this compartment. The retinal pigment-epithelium cell, which has digestion of photoreceptor outer segments as its primary function, may be an appropriate candidate.

Interestingly, we found a reduced AMD risk for subjects carrying the $\epsilon 4$ allele, whereas for most other neurodegenerative disorders the risk is increased for these subjects. Isoform-specific alterations in apoE-lipoprotein metabolism consist of differences in net charge (Davignon et al. 1988) and in total serum level (Utermann 1985) and brain level (Bertrand et al. 1995) of apoE. Recently, it has been shown that the isoforms also differ in cell-specific binding properties (Guillaume et al. 1996). apoE-mediated binding, internalization, and degradation of lipids in the CNS appear to be different for each apoE isoform, depending on the type of target cell. A possible interpretation of our findings is that apoE isoforms in the macular area may either differ in binding affinity or elicit a response different than that at other sites in the nervous system. Since it is not immediately clear how the APOE alleles may be a source of genetic risk for AMD, it will be intriguing to investigate whether accumulation of deposits in AMD occurs in an isoformdependent manner.

An alternative explanation for our findings is that the $\epsilon 4$ allele is associated with a distinct mutation in a gene in linkage disequilibrium with APOE. This may be the gene that actually determines susceptibility to AMD. According to the August 1997 OMIM (Online Mendelian Inheritance in Man), 20-30 genes are located in the immediate vicinity of APOE, and they may be considered in this context; among these genes, we could not find an obvious candidate gene for retinal disease.

To conclude, we have shown a significant association between APOE and AMD in a general population of elderly people, and we have immunohistochemically localized apoE in defining lesions of AMD. Although in need of confirmation, our data further emphasize the role of APOE in neurodegeneration and may indicate that we have identified a susceptibility gene for AMD.

\section{Acknowledgments}

This work was presented at the Macula Society meeting in Tucson, February 22, 1998. We thank the Bio Implant Services Foundation and the cornea bank of the Netherlands Ophthalmic Research Institute, for assistance in obtaining postmortem eyes; Anita Wehnert and Hubert Backhovens, for genotyping; Ada Hooghart and Corina Brussee, for grading fundus transparencies; and Jacqueline Assink and Arthur Bergen, for constructive review of the manuscript. This work was supported by the Nestor program (Ministry of Health and Ministry of Education); the Netherlands Organization for Scientific Research; Topcon Europe BV; the Netherlands Society for Prevention of Blindness; Landelijke Stighting voor Blinden en Slechtzienden; Stichting Fondsenwervingsacties Volksgezondheid; Stichting Blindenpenning; Rotterdamse Vereniging voor Blindenbelangen; Stichting Physicotherapeutisch Insti- 
tuut; Stichting voor Ooglijders; Stichting Blindenhulp; Stichting Rotterdamse Oogheelkundige Onderzoeks Stichting; Flemish Biotechnology Programme grant COT-04; and G.Ph. Verhagenstichtung.

\section{Electronic-Database Information}

Online Mendelian Inheritance in Man (OMIM), http:// www.ncbi.nlm.nih.gov/Omim

\section{References}

Al-Chalabi A, Enayat ZE, Bakker MC, Sham PC, Ball DM, Shaw CE, Lloyd CM, et al (1996) Association of apolipoprotein $\mathrm{E} \epsilon 4$ allele with bulbar-onset motor neuron disease. Lancet 347:159-160

Allikmets R, Shroyer NF, Singh N, Seddon JM, Lewis RA, Bernstein PS, Peiffer A, et al (1997) Mutation of the Stargardt disease gene (ABCR) in age-related macular degeneration. Science 277:1805-1807

Amaratunga A, Abraham CR, Edwards RB, Sandell JH, Schreibert BM, Fine RE (1996) Apolipoprotein E is synthesized in the retina by Müller glial cells, secreted into the vitreous, and rapidly transported into the optic nerve by retinal ganglion cells. J Biol Chem 271:5628-5632

Amouyel P, Vidal O, Launay JM, Laplanche JL (1994) The apolipoprotein E alleles as major susceptibility factors for Creuzfeldt-Jakob disease: the French research group on epidemiology of human spongiform encephalopathies. Lancet 344:1315-1318

Attebo K, Mitchell P, Smith W (1996) Visual acuity and the causes of visual loss in Australia. Ophthalmology 103: 357-364

Bertrand P, Poirier J, Oda T, Finch CE, Pasinetti GM (1995) Association between apolipoprotein E genotype with brain levels of apolipoprotein $\mathrm{E}$ and apolipoprotein $\mathrm{J}$ (clusterin) in Alzheimer's disease. Mol Brain Res 33:174-178

Bird AC, Bressler NM, Bressler SB, Chishol IH, Coscas G, Davis MD, de Jong PTVM, et al (1995) An international classification and grading system for age-related maculopathy and age-related macular degeneration: the International ARM Epidemiological Study Group. Surv Ophthalmol 39:367-374

Boyles JK, Zoellner CD, Anderson LJ, Kosik LM, Pitas RE, Weisgraber KH, Hui DY, et al (1989) A role for apolipoprotein E, apolipoprotein A-I, and low density lipoprotein receptors in cholesterol transport during regeneration and remyelination of the rat sciatic nerve. J Clin Invest 83: 1015-1031

Davignon J, Gregg RE, Sing CF (1988) Apolipoprotein E polymorphism and atherosclerosis. Arteriosclerosis 8:1-21

Evans K, Fryer A, Inglehearn C, Duvall-Young J, Whittaker JL, Gregory CY, Butler R, et al (1994) Genetic linkage of cone-rod retinal dystrophy to chromosome $19 \mathrm{q}$ and evidence for segregation distortion. Nat Genet 6:210-213

Farrer LA, Cupples LA, Haines JL, Hyman B, Kukull WA, Mayeux R, Myers RH, et al (1997) Effects of age, sex, and ethnicity on the association between apolipoprotein E genotype and Alzheimer disease: a meta-analysis. JAMA 278: 1349-1356
Goldstein JL, Basu SK, Brown MS (1983) Receptor-mediated endocytosis of low-density lipoprotein in cultured cells. Methods Enzymol 98:241-261

Green WR, Enger C (1993) Age-related macular degeneration histopathologic studies: the 1992 Lorenz E. Zimmerman Lecture. Ophthalmology 100:1519-1535

Gregory CY, Evans K, Wijesuriya SD, Kermani S, Jay MR, Plant C, Cox N, et al (1996) The gene responsible for autosomal dominant Doyne's honeycomb retinal dystrophy (DHRD) maps to chromosome 2p16. Hum Mol Genet 5: 1055-1059

Grindle CFJ, Marshall J (1978) Ageing changes in Bruch's membrane and their functional implications. Trans Ophthalmol Soc UK 98:172-175

Guillaume D, Bertrand P, Dea D, Davignon J, Poirier J (1996) Apolipoprotein $\mathrm{E}$ and low density lipoprotein binding and internalization in primary cultures of rat astrocytes: isoformspecific alterations. J Neurochem 66:2410-2418

Heiba IM, Elston RC, Klein BEK, Klein R (1994) Sibling correlations and segregation analysis of age-related macular degeneration: the Beaver Dam Eye Study. Genet Epidemiol 11: $51-67$

Hofman A, Grobbee DE, de Jong PTVM, van den Ouweland FA (1991) Determinants and disabilities in the elderly: the Rotterdam Elderly Study. Eur J Epidemiol 7:403-422

Hoyng CB, Heutink P, Testers L, Pinckers A, Deutman AF, Oostra BA (1996) Autosomal dominant central areolar choroidal dystrophy caused by a mutation in codon 142 in the peripherin/RDS gene. Am J Ophthalmol 121:623-629

Ignatius MJ, Gebicke-Harter PJ, Skene JH, Schilling JW, Weisgraber KH, Mahley RW, Shooter EM (1986) Expression of apolipoprotein E during nerve degeneration and regeneration. Proc Natl Acad Sci USA 83:1125-1129

Keen TJ, Inglehearn CF, Kim R, Bird AC, Bhattacharya S (1994) Retinal pattern dystrophy associated with a 4 bp insertion at codon 140 in the RDS-peripherin gene. Hum Mol Genet 3:367-368

Kervinen K, Savolainen MJ, Salokannel J, Hynninen A, Heikkinen J, Ehnholm C, Koistinen MJ, et al (1994) Apolipoprotein $\mathrm{E}$ and B polymorphisms-longevity factors assessed in nonagenarians. Atherosclerosis 105:89-95

Klaver CCW, Wolfs RCW, van Duijn CM, Hofman A, de Jong PTVM (1997) Familial aggregation of age-related macular degeneration in the Rotterdam Study. Invest Ophthalmol Vis Sci Suppl 38:S967

Klaver CCW, Wolfs RCW, Vingerling JR, Hofman A, De Jong PTVM (1998) Age-specific prevalence and causes of blindness and visual impairment in an older population. Arch Ophthalmol 116:653-658

Klein R, Wang Q, Klein BEK, Moss SE, Meuer SM (1995) The relationship of age-related maculopathy, cataract and glaucoma to visual acuity. Invest Ophthalmol Vis Sci 36: 182-191

Kliffen M, van der Schaft TL, Mooy CM, de Jong PTVM (1997) Morphologic changes in age-related maculopathy. Microsc Res Tech 36:106-122

Kowal RC, Herz J, Goldstein JL, Esser V, Brown MS (1989) Low density lipoprotein receptor-related protein mediates uptake of cholesterol esters derived from apolipoprotein E- 
enriched lipoproteins. Proc Natl Acad Sci USA 86: 5810-5814

Kuhrt H, Hartig W, Grimm D, Faude F, Kasper M, Reichenbach A (1997) Changes in CD44 and apolipoprotein E immunoreactivities due to retinal pathology of man and rat. J Hirnforsch 38:223-229

Mahley RW (1988) Apolipoprotein E: cholesterol transport protein with expanding role in cell biology. Science 240: 622-630

Nakazawa M, Kikawa E, Chida Y, Tamai M (1994) Asn244His mutation of the peripherin/RDS gene causing autosomal dominant cone-rod degeneration. Hum Mol Genet 3:1195-1196

Namba Y, Tomonaga M, Kawasaki H, Otoma E, Ikeda K (1991) Apolipoprotein E immunoreactivity in cerebral amyloid deposits and neurofibrillary tangles in Alzheimer's disease and kuru plaque amyloid in Creutzfeld-Jakob disease. Brain Res 541:163-166

Nichols BE, Sheffield VC, Vandenburgh K, Drack AV, Kimura AE, Stone EM (1993) Butterfly-shaped pigment dystrophy of the fovea caused by a point mutation in codon 167 of the RDS gene. Nat Genet 3:202-206

Olaisen B, Telsberg P, Gedde-Dahl T Jr (1982) The locus for apolipoprotein $\mathrm{E}$ (apoE) is linked to the complement component C3 (C3) locus on chromosome 19 in man. Hum Genet 62:233-236

Pitas RE, Boyles JK, Lee SH, Hui DY, Weisgraber KH (1987) Lipoproteins and their receptors in the central nervous system: characterization of the lipoproteins in cerebrospinal fluid and identification of apolipoprotein B, E (LDL) receptors in the brain. J Biol Chem 262:14352-14360

Poirier J, Baccichet A, Dea D, Gauthier S (1993) Cholesterol synthesis and lipoprotein reuptake during synaptic remodelling in hippocampus in adult rats. Neuroscience 55:81-90

Poirier J, Minnich A, Davignon J (1995) Apolipoprotein E, synaptic plasticity and Alzheimer's disease. Ann Med 27: 663-670

Sarks SH (1976) Aging and degeneration in the macular region: a clinico-pathological study. $\mathrm{Br} \mathrm{J}$ Ophthalmol 60: 324-341

Seddon JM, Ajani UA, Mitchell B (1997) Familial aggregation of age-related maculopathy. Am J Ophthalmol 123:199-206

Small KW, Syrquin M, Mullen L, Gehrs K (1996) Mapping autosomal dominant cone degeneration to chromosome 17p. Am J Ophthalmol 121:13-18

Small KW, Weber JL, Roses A, Lennon F, Vance JM, PericakVance P (1992) North Carolina macular dystrophy is assigned to chromosome 6. Genomics 13:681-685

Smit M, de Knijff P, Rosseneu M, Bury J, Klasen E, Frants R, Havekes L (1988) Apolipoprotein E polymorphism in the
Netherlands and its effect on plasma lipid and apolipoprotein levels. Hum Genet 80:287-292

Sommer A, Tielsch JM, Katz J, Quickley HA, Gottsch JJ, Javitt JC, Martone JF, et al (1991) Racial differences in the causespecific prevalence of blindness in east Baltimore. N Engl J Med 325:1412-1417

Stone EM, Nichols BE, Kimura AE, Weingeist TA, Drack A, Sheffield VC (1994) Clinical features of a Stargardt-like dominant progressive macular dystrophy with genetic linkage to chromosome 6q. Arch Ophthalmol 112:765-772

Stone EM, Nichols BE, Streb LM, Kimura AE, Sheffield VC (1992) Genetic linkage of vitelliform macular degeneration (Best's disease) to chromosome 11q13. Nat Genet 1: 246-250

Strittmatter WJ, Saunders AM, Schmechel DE, Pericak-Vance MA, Enghild J, Salvesen GS, Roses AD (1993) Apolipoprotein E: high avidity binding to $\beta$-amyloid and increased frequency of type 4 allele in late-onset familial Alzheimer disease. Proc Natl Acad Sci USA 90:1977-1981

Utermann G (1985) Apolipoprotein E mutants, hyperlipidemia, and atherosclerosis. Adv Exp Med Biol 183:173-188 van der Schaft TL, Mooy CM, de Bruijn WC, Orom FG, Mulder PG, de Jong PTVM (1992) Histologic features of the early stages of age-related macular degeneration: a statistical analysis. Ophthalmology 99:278-286

Van Duijn CM, de Knijff P, Cruts M, Wehnert A, Havekes LM, Hofman A, Van Broeckhoven C (1994) Apolipoprotein E4 allele in a population-based study of early-onset Alzheimer's disease. Nat Genet 7:74-78

Vingerling JR, Dielemans I, Hofman A, Grobbee DE, Hijmering M, Kramer CFL, de Jong PTVM (1995) The prevalence of age-related maculopathy in the Rotterdam Study. Ophthalmology 102:205-210

Weber BHF, Vogt G, Pruett RC, Stohr H, Felbor U (1994) Mutations in the tissue inhibitor of metalloproteinases-3 (TIMP3) in patients with Sorsby's fundus dystrophy. Nat Genet 8:352-355

Weleber RG, Carr RE, Murphey WH, Sheffield VC, Stone EM (1993) Phenotypic variation including retinitis pigmentosa, pattern dystrophy, and fundus flavimaculus in a single family with a deletion of codon 153 or 154 of the peripheral/RDS gene. Arch Ophthalmol 111:1531-1542

Wells J, Wroblewski J, Keen J, Inglehearn C, Jubb C, Eckstein C, Jay M, et al (1993) Mutations in the human retinal degeneration slow (RDS) gene can either cause retinitis pigmentosa or macular dystrophy. Nat Genet 3:213-218

Wenham PR, Price WH, Blundell G (1991) Apoliprotein E genotyping by one-stage PCR. Lancet 337:1158-1159

Wisniewski T, Frangione B (1992) Apolipoprotein E: a pathological chaperone protein in patients with cerebral and systemic amyloid. Neurosci Lett 135:235-238 